\title{
Prereaction of Citrus tristeza virus (CTV) Specific Antibodies and Labeled Secondary Antibodies Increases Speed of Direct Tissue Blot Immunoassay for CTV
}

\author{
Youjian Lin, College of Plant Protection, Fujian Agriculture \& Forestry University, Fuzhou, Fujian 350002, P. R. \\ China; Phyllis A. Rundell, Indian River Research and Education Center, University of Florida, Fort Pierce 34945, \\ USA; Lianhui Xie, Institute of Plant Virology, Fujian Agriculture\& Forestry University, Fuzhou, Fujian 350002, P. \\ R. China; and Charles A. Powell, Indian River Research and Education Center, University of Florida, Fort Pierce \\ 34945, USA
}

\begin{abstract}
Lin, Y., Rundell, P. A., Xie, L., and Powell, C. A. 2006. Prereaction of Citrus tristeza virus (CTV) specific antibodies and labeled secondary antibodies increases speed of direct tissue blot immunoassay for CTV. Plant Dis. 90:675-679.
\end{abstract}

An improved direct tissue blot immunoassay (DTBIA) procedure for detection of Citrus tristeza virus (CTV) within $1 \mathrm{~h}$ is described. Prints of fresh young stems of citrus plants that were infected or not infected with CTV were made by gently and evenly pressing the fresh-cut surface of the stems onto a nitrocellulose membrane. The tissue blots were air-dried for $5 \mathrm{~min}$, incubated with prereaction solutions of CTV-specific antibodies and labeled secondary antibodies, goat anti-mouse Ig $(\mathrm{H}+\mathrm{L})$-alkaline phosphatase conjugate or goat anti-rabbit IgG alkaline phosphatase conjugate, for up to $20 \mathrm{~min}$, rinsed with PBST buffer for $5 \mathrm{~min}$, and immersed into an NBT-BCIP substrate solution for 15 to $20 \mathrm{~min}$. Then the blots were rinsed in water for a few seconds to stop the reactions, and the results were observed and recorded under a light microscope. All samples from greenhouse plants that were infected with CTV decline inducing isolate T-36 were positive to CTV-specific polyclonal antibody 1212 (PCA 1212) and monoclonal antibodies 17G11 (MAb 17G11) and MCA13 (MAb MCA13), whereas samples from greenhouse plants infected with non-decline-inducing isolate T-30 were positive to PCA 1212 and MAb 17G11, but not to MAb MCA13. The noninfected greenhouse plants were negative to all of the antibodies. The improved DTBIA was at least as reliable as other immunological procedures and almost as reliable as polymerase chain reaction for detecting CTV in field trees. The improved DTBIA enables the detection of CTV within $1 \mathrm{~h}$ by having a prereaction of CTV-specific antibodies and labeled secondary antibodies in solutions before they are applied to the tissue blots. This DTBIA procedure may be useful in detecting other plant viruses and other pathogens such as bacteria and fungi.

Additional keywords: CTV isolates, diagnosis

Direct tissue blot immunoassay (DTBIA), also called tissue-printing immunoassay, is a simple and rapid immunoassay procedure for detection of plant viruses, phytoplasma, and plant components $(2,3,5,7)$. Plant tissue samples are blotted directly onto a nitrocellulose membrane, and the antigens are detected with specific antibodies $(1,3,5,7,13)$. Because antigens from the cut surface of infected tissue bind directly without dilution by proteins from noninfected cells in other locations, the signals formed in localized areas are strong and easily detected. Even samples that induce weak positive reactions by enzyme-

Corresponding author: Charles A. Powell

E-mail: capowell@ifas.ufl.edu

Florida Agriculture Experiment Station Journal Series: R-10841.

Accepted for publication 3 January 2006.

DOI: 10.1094/PD-90-0675

(C) 2006 The American Phytopathological Society linked immunosorbent assay (ELISA) or by other regular immunoblots usually give clear results with DTBIA, since only one group of infected cells is needed to impart a clear signal (3). Also, DTBIA can provide direct information about distribution of the virus within the host. There are four well-documented basic DTBIA procedures: a direct procedure, an indirect procedure, a direct biotin-streptavidin (BIO/SA) procedure, and an indirect $\mathrm{BIO} / \mathrm{SA}$ procedure (3). The indirect procedure, in which the blotted membrane is exposed to unlabeled CTV-specific antibodies and then to commercially prepared alkaline phosphaselabeled secondary antibodies (goat antirabbit IgG for polyclonals and goat antimouse $\operatorname{Ig}[\mathrm{H}+\mathrm{L}]$ for monoclonals), is widely employed for the detection of plant viruses because it is convenient to obtain unlabeled virus-specific antibodies and alkaline phosphase-labeled secondary antibodies. The indirect procedure usually provides results within 4 to $7 \mathrm{~h}(2,3,5)$, whereas the direct procedure provides results in a shorter time, usually 3 to $5 \mathrm{~h}$.
However, the direct procedure has the disadvantage that it requires virusspecific antibodies conjugated to alkaline phosphatase that are often not readily available (8).

Garnsey et al. (3) first reported the application of DTBIA to detect Citrus tristeza virus (CTV). It has been demonstrated that DTBIA is a reliable and sensitive procedure for detection of CTV $(3,4,7)$. The sensitivity of DTBIA for CTV detection compares favorably with other immunoassay procedures, or even reverse transcription-polymerase chain reaction (RT-PCR) $(3,4,6,7)$. However, the assay time and cost are major issues for research and commercial agriculture. Reducing the time required for accurate virus detection would have significance to both researchers and growers because shorter assay times may reduce labor costs. Also, the more rapid the diagnostic procedure, the faster a grower can make decisions to help control. In this paper, we describe an improved DTBIA procedure that enables the detection of CTV within $1 \mathrm{~h}$ by incubating the blots of samples with prereaction solutions of CTV-specific antibodies and labeled secondary antibodies.

\section{MATERIALS AND METHODS}

Source of virus. The Florida CTV isolates T-36 (decline-inducing isolate, DI) and T-30 (non-decline-inducing isolate, NDI) were used in initial greenhouse tests. The first causes vein clearing, stunting, and stem pitting on Mexican lime (Citrus aurantifolia (Christm.) Swingle) and decline of sweet orange $(C$. sinensis L.) on sour orange (C. aurantium L.) rootstock, whereas the latter only causes mild symptoms on Mexican lime and no decline symptoms on sweet orange on sour orange rootstock (10-12). Each of the CTV isolates was in 10 Mexican lime plants (20 total infected plants). Ten uninfected Mexican lime plants were used as controls. All infected and uninfected plants were maintained in a quarantine greenhouse at the Indian River Research and Education Center, University of Florida, Fort Pierce. In tests of field samples, 50 grapefruit $(C$. paradisi Macf.) and 50 sweet orange trees on sour orange rootstock known to be infected with DI or NDI CTV isolates 
were the sample sources. Ten uninfected sweet orange and 10 uninfected grapefruit in the greenhouse served as controls.

Tissue samples and blotting. According to our previous experience, the young stems of CTV-infected plants are the most suitable tissues for detection of CTV with the DTBIA procedure (7). Thus, all tissue samples used in this test were young stems taken from plants either infected with CTV or noninfected. Tissue blots on nitrocellulose membrane (Bio-Rad Laboratories, Hercules, CA) were made from stems of citrus plants that were infected or noninfected with CTV as described by Garnsey et al. (3).

Sources of antibodies. CTV-specific polyclonal and monoclonal antibodies (PCA and MAb) were used. The polyclonal antibody was PCA 1212 (7) provided by S. M. Garnsey. The monoclonal antibodies were MAb-17G11, generated and produced at the Indian River Research and Education Center (7,9), and MAb MCA13 $(7,10)$, provided by S. M. Garnsey. Purified IgG was used as antibody sources for PCA 1212 and MAb MCA13. Undiluted cell-culture fluid was used as the source for MAb 17G11. The labeled secondary antibodies were goat anti-mouse Ig $(\mathrm{H}+\mathrm{L})$-alkaline phosphatase conjugate (GAM-AP), used to react to CTV MAbs, and goat anti-rabbit IgG alkaline phosphatase conjugate (GAR-AP), used to react to CTV PCA. The GAM-AP and GAR-AP were purchased from Southern Biotechnology Associates, Inc., Birmingham, AL, and Sigma Chemical Co., Saint Louis, MO, respectively.

Table 1. Effect of the ratios of Citrus tristeza virus (CTV)-specific antibodies to labeled secondary antibodies in the prereaction solutions on the detection of CTV in improved direct tissue blot immunoassay (DTBIA)

\begin{tabular}{|c|c|c|c|c|c|}
\hline \multirow{2}{*}{$\begin{array}{l}\text { Combination } \\
\text { of antibodies }{ }^{y}\end{array}$} & & & \multicolumn{3}{|c|}{ Isolate $^{x}$} \\
\hline & \multicolumn{2}{|c|}{ Concentrations of antibodies } & T-36 & T-30 & Healthy \\
\hline PCA1212 + & PCA1212 $(\mu \mathrm{g} / \mathrm{ml})$ & GAR-AP (dilution) & & & \\
\hline \multirow[t]{3}{*}{ GAR-AP } & 1 & $1 / 20,000$ & $+-^{\mathrm{z}}$ & - & - \\
\hline & 1 & $1 / 10,000$ & + & +- & - \\
\hline & 1 & $1 / 5,000$ & ++ & ++ & - \\
\hline \multirow{4}{*}{$\begin{array}{l}\text { MAb 17G11 + } \\
\text { GAM-AP }\end{array}$} & MAb17G11 $(\mu \mathrm{g} / \mathrm{ml})$ & GAM-AP (dilution) & & & \\
\hline & Unknown & $1 / 4,000$ & +- & +- & - \\
\hline & Unknown & $1 / 2,000$ & ++ & + & - \\
\hline & Unknown & $1 / 1,000$ & +++ & ++ & - \\
\hline \multirow{4}{*}{$\begin{array}{l}\text { MAb MCA13 + } \\
\text { GAM-AP }\end{array}$} & MAb MCA13 $(\mu \mathrm{g} / \mathrm{ml})$ & GAM-AP(dilution) & & & \\
\hline & 1 & $1 / 4,000$ & - & - & - \\
\hline & 1 & $1 / 2,000$ & + & - & - \\
\hline & 1 & $1 / 1,000$ & +++ & - & - \\
\hline
\end{tabular}

x CTV isolates: T36, a Florida decline-inducing isolate; T-30, a Florida non-decline-inducing isolate.

y PCA 1212, a CTV polyclonal antibody (PAC) generated against purified CTV virions in rabbits. MAb MCA13, a CTV monoclonal antibody (MAb) that reacts with Florida decline-inducing isolates of CTV, but not non-decline-inducing isolates of CTV. MAb-17G11, a CTV broad range monoclonal antibody that reacts with most isolates of CTV. GAR-AP, a goat anti-rabbit IgG alkaline phosphatase conjugate; GAM-AP, a goat anti-mouse Ig $(\mathrm{H}+\mathrm{L})$-alkaline phosphatase conjugate. The data were from 20-min incubation with the prereaction solutions.

${ }^{\mathrm{z}}$ Relative signal intensity of improved DTBIA reactions observed under a microscope at $\times 10$ to $\times 25$ : - , negative reactions; +-, a few light and vague purple spots; +, weak reactions, a few typical purple spots; ++, strong positive reactions, many typical purple spots; +++, very strong reactions, many typical positive spots arranged in a ring; ++++, strongest positive reactions observed, a dark and continuing purple ring located in the phloem tissue. Results are based on the mean of 10 replications (plants). tion. A positive signal was the development of purple color in the region of the blot associated with phloem cells, and a negative reaction was absence of purple color in the whole blot $(3,7)$. The improved DTBIA procedure had two steps less than the regular DTBIA. Also, the time periods of incubation and rinsing in the improved DTBIA assay were shorter.

The effects of the ratios of CTV-specific antibodies to the labeled secondary antibodies, the incubation period of the blots with the prereaction solution, and the length of storage of the prereaction solution on the detection of CTV with the improved DTBIA procedure were also investigated. For MAb MCA13 or MAb 17G11 and GAM-AP, there were three ratios: 1.0 $\mu \mathrm{g} / \mathrm{ml}$ to $1 / 4,000$ dilution, $1.0 \mu \mathrm{g} / \mathrm{ml}$ to $1 / 2,000$ dilution, and $1.0 \mu \mathrm{g} / \mathrm{ml}$ to $1 / 1,000$ dilution. For PCA 1212 and GAR-AP, the three ratios were $1.0 \mu \mathrm{g} / \mathrm{ml}$ to $1 / 20,000$ dilution, $1.0 \mu \mathrm{g} / \mathrm{ml}$ to $1 / 10,000$ dilution, and $1.0 \mu \mathrm{g} / \mathrm{ml}$ to $1 / 5,000$ dilution. The treatments of the incubation with the antibody prereaction solutions were $10,20,30$, or $40 \mathrm{~min}$. The treatments of the storage of the prereaction solutions were $5 \mathrm{~min}, 30$ min, $60 \mathrm{~min}, 24 \mathrm{~h}$, and $48 \mathrm{~h}$ at $4^{\circ} \mathrm{C}$ or room temperature. The experiments were conducted twice. There were three replicated blots for each treatment in each test.

ELISA and RT-PCR. ELISA and RTPCR were performed as previously described (4).

\section{RESULTS}

Detection of CTV by improved DTBIA. With $1.0 \mu \mathrm{g} / \mathrm{ml}$ of MAb 17G11 and a $1 / 1,000$ dilution of GAM-AP and with $1.0 \mu \mathrm{g} / \mathrm{ml}$ of PAC 1212 and a 1/5,000 dilution of GAR-AP, and 20 min prereaction solution incubation, the improved DTBIA procedure gave strong positive signals in all samples infected with CTV isolates $\mathrm{T}-36$ or $\mathrm{T}-30$, but no positive signals in the noninfected control samples. With MAb MCA13 at $1.0 \mu \mathrm{g} / \mathrm{ml}$ and a 1/1,000 dilution of GAM-AP, the improved DTBIA procedure gave positive signals in all samples that were infected with decline-inducing isolate T-36, but not in samples that were infected with nondecline-inducing isolate $\mathrm{T}-30$ or noninfected samples (Tables 1 to 3). This result would be expected since MAb MCA13 does not react with T-30. Results from the improved DTBIA procedure in the test were identical to those from the regular DTBIA procedure. The sensitivity of the improved DTBIA procedure with the prereaction solution of $1.0 \mu \mathrm{g} / \mathrm{ml} \mathrm{CTV-}$ specific antibodies and 1/1,000 dilution of labeled secondary antibodies and a 20 min incubation was equal to that of the regular DTBIA procedure. The 1-h DTBIA was as reliable as regular DTBIA, ELISA, and PCR in detecting CTV in field sweet oranges and grapefruit trees (Table 4). 
Effect of ratios of CTV-specific antibodies to labeled secondary antibodies on detection sensitivity. The detection sensitivity of the improved DTBIA procedure for CTV was affected by the ratio of CTV-specific antibodies to labeled secon- dary antibodies. The positive signals increased significantly with increase in concentration of the labeled secondary antibodies used in the solutions containing $1.0 \mu \mathrm{g} / \mathrm{ml} \mathrm{CTV} \mathrm{antibody.} \mathrm{When} \mathrm{the} \mathrm{blots}$ were air-dried for $5 \mathrm{~min}$, incubated with

Table 2. Effect of incubation with the prereaction solutions of Citrus tristeza virus (CTV)-specific antibodies and labeled secondary antibodies on the detection of CTV in improved direct tissue blot immunoassay (DTBIA) ${ }^{\mathrm{w}}$

\begin{tabular}{|c|c|c|c|c|c|}
\hline \multirow[b]{2}{*}{ Combination of antibodies ${ }^{y}$} & \multirow[b]{2}{*}{ Isolate } & \multicolumn{4}{|c|}{ Incubation time $^{x}$} \\
\hline & & $10 \mathrm{~min}$ & $20 \mathrm{~min}$ & $30 \mathrm{~min}$ & $40 \mathrm{~min}$ \\
\hline \multirow[t]{3}{*}{ PCA1212 + GAR-AP } & $\mathrm{T}-36$ & $-\mathrm{z}$ & ++ & ++ & +++ \\
\hline & T-30 & +- & ++ & ++ & +++ \\
\hline & Healthy & - & - & - & - \\
\hline \multirow[t]{3}{*}{ MAb 17G11 + GAM-AP } & $\mathrm{T}-36$ & +- & +++ & +++ & ++++ \\
\hline & T-30 & - & ++ & ++ & +++ \\
\hline & Healthy & - & - & - & - \\
\hline \multirow[t]{3}{*}{ MAb MCA13 + GAM-AP } & $\mathrm{T}-36$ & - & +++ & ++ & ++++ \\
\hline & T-30 & - & - & - & - \\
\hline & Healthy & - & - & - & - \\
\hline
\end{tabular}

${ }^{\text {w }}$ Data shown here were from the tests using $1.0 \mu \mathrm{g} / \mathrm{ml} \mathrm{CTV-specific} \mathrm{antibodies} \mathrm{or} \mathrm{MAb} \mathrm{17G11} \mathrm{culture}$ fluid mated with a 1/1,000 dilution of GAM-AP or 1/5,000 dilution of GAR-AP. Prereaction solutions of CTV antibodies and labeled secondary antibodies were prepared with PBS or PBS containing $1 \% \mathrm{BSA}$, and used within $30 \mathrm{~min}$.

$\mathrm{x}$ Time of incubation with prereaction solutions.

y PCA 1212, a CTV polyclonal antibody (PAC) generated against purified CTV virions in rabbits. MAb MCA13, a CTV monoclonal antibody (MAb) that reacts with Florida decline-inducing isolates of CTV, but not non-decline-inducing isolates of CTV. MAb-17G11, a CTV broad range monoclonal antibody that reacts with most isolates of CTV. GAR-AP, a goat anti-rabbit IgG alkaline phosphatase conjugate; GAM-AP, a goat anti-mouse Ig $(\mathrm{H}+\mathrm{L})$-alkaline phosphatase conjugate. The data were from 20-min incubation with the prereaction solutions.

${ }^{\mathrm{z}}$ Relative signal intensity of improved DTBIA reactions observed under a microscope at $\times 10$ to $\times 25$ : -, negative reactions; +-, a few light and vague purple spots; + , weak reactions, a few typical purple spots; ++, strong positive reactions, many typical purple spots; +++, very strong reactions, many typical positive spots arranged in a ring; ++++ , strongest positive reactions observed, a dark and continuing purple ring located in the phloem tissue. Results are based on the mean of 10 replications (plants).

prereaction solutions for $20 \mathrm{~min}$, rinsed with PBST for $5 \mathrm{~min}$, and developed with NBT-BCIP for 15 to $20 \mathrm{~min}$, the ratio of $1.0 \mu \mathrm{g} / \mathrm{ml}$ to $1 / 4,000$ dilution (CTV antibody to labeled secondary antibody) gave the weakest positive signals and sometimes failed to give positive signals. The ratio of $1.0 \mu \mathrm{g} / \mathrm{ml}$ to $1 / 1,000$ dilution gave the strongest positive signals in all the positive samples, and the ratio of $1.0 \mu \mathrm{g} / \mathrm{ml}$ to 1/2,000 dilution gave intermediate positive signals. There were no positive signals in any of the negative control samples at any of the CTV antibody and secondary antibody combinations (Table 1).

Effect of prereaction solution incubation period on detection sensitivity. The prereaction solution incubation period significantly affected the sensitivity of the improved DTBIA procedure. Longer incubation times with the prereaction solution (CTV antibody to labeled secondary antibody: $1.0 \mu \mathrm{g} / \mathrm{ml}$ to $1 / 1,000$ dilution) in the improved DTBIA test yielded stronger positive signals. Improved DTBIA with a 10-min prereaction solution incubation period did not produce any positive signals in most positive samples in the test; only a few positive samples produced very weak positive signals. With 20 to $40 \mathrm{~min}$ of prereaction solution incubation, the improved DTBIA detected CTV in all positive samples. The 40-min incubation gave the strongest positive signals in positive samples among the four incubation treatments. However, a 20-min incubation gave strong enough signals for reliable detection of CTV (Table 2).

Table 3. Effect of storage of prereaction solutions on detection of Citrus tristeza virus (CTV) in improved direct tissue blot immunoassay (DTBIA) ${ }^{\mathrm{x}}$

\begin{tabular}{|c|c|c|c|c|c|c|c|}
\hline \multirow[b]{2}{*}{ Combination of antibodies ${ }^{y}$} & \multirow[b]{2}{*}{ Incubation time } & \multirow[b]{2}{*}{ Isolate } & \multicolumn{5}{|c|}{ Storage time } \\
\hline & & & $5 \mathrm{~min}$ & $30 \mathrm{~min}$ & $60 \mathrm{~min}$ & $24 \mathrm{~h}$ & $48 \mathrm{~h}$ \\
\hline \multirow{6}{*}{ PCA1212 + GAR-AP } & $20 \mathrm{~min}$ & T-36 & $++^{\mathrm{z}}$ & ++ & ++ & +- & + \\
\hline & & T-30 & ++ & ++ & + & +- & +- \\
\hline & & Healthy & - & - & - & - & - \\
\hline & $40 \mathrm{~min}$ & $\mathrm{~T}-36$ & +++ & +++ & +++ & ++ & +++ \\
\hline & & T-30 & +++ & +++ & ++ & ++ & ++ \\
\hline & & Healthy & - & - & - & - & - \\
\hline \multirow[t]{6}{*}{ MAb 17G11 + GAM-AP } & $20 \mathrm{~min}$ & $\mathrm{~T}-36$ & +++ & +++ & ++ & +- & +- \\
\hline & & $\mathrm{T}-30$ & ++ & ++ & + & +- & + \\
\hline & & Healthy & - & - & - & - & - \\
\hline & $40 \mathrm{~min}$ & $\mathrm{~T}-36$ & ++++ & ++++ & +++ & ++ & +++ \\
\hline & & $\mathrm{T}-30$ & +++ & +++ & ++ & ++ & ++ \\
\hline & & Healthy & - & - & - & - & - \\
\hline \multirow[t]{6}{*}{ MAb MCA13 + GAM-AP } & $20 \mathrm{~min}$ & $\mathrm{~T}-36$ & ++++ & ++ & ++ & +- & +- \\
\hline & & $\mathrm{T}-30$ & - & - & - & - & - \\
\hline & & Healthy & - & - & - & - & - \\
\hline & $40 \mathrm{~min}$ & $\mathrm{~T}-36$ & +++ & +++ & +++ & ++ & ++ \\
\hline & & $\mathrm{T}-30$ & - & - & - & - & - \\
\hline & & Healthy & - & - & - & - & - \\
\hline
\end{tabular}

${ }^{\mathrm{x}}$ Data shown were from tests of improved DTBIA procedure with 20- and 40-min incubations, respectively. Data from other incubation treatments were not shown.

y PCA 1212, a CTV polyclonal antibody (PAC) generated against purified CTV virions in rabbits. MAb MCA13, a CTV monoclonal antibody (MAb) that reacts with Florida decline-inducing isolates of CTV, but not non-decline-inducing isolates of CTV. MAb-17G11, a CTV broad range monoclonal antibody that reacts with most isolates of CTV. GAR-AP, a goat anti-rabbit IgG alkaline phosphatase conjugate; GAM-AP, a goat anti-mouse Ig (H+L)-alkaline phosphatase conjugate. The data were from 20-min incubation with the prereaction solutions.

${ }^{\mathrm{z}}$ Relative signal intensity of improved DTBIA reactions observed under a microscope at $\times 10$ to $\times 25:-$, negative reactions; +-, a few light and vague purple spots; +, weak reactions, a few typical purple spots; ++, strong positive reactions, many typical purple spots; +++, very strong reactions, many typical positive spots arranged in a ring; ++++, strongest positive reactions observed, a dark and continuing purple ring located in the phloem tissue. Results are based on the mean of 10 replications (plants). 
Table 4. Comparison of testing costs among the regular and improved direct tissue blot immunoassay (DTBIA), enzyme-linked immunosorbent assay (ELISA), and reverse transcription-polymerase chain reaction (RT-PCR) for detection of Citrus tristeza virus (CTV) in field grapefruit and sweet orange trees

\begin{tabular}{|c|c|c|c|c|c|c|}
\hline \multirow{2}{*}{$\begin{array}{l}\text { Detection } \\
\text { procedure }\end{array}$} & \multicolumn{4}{|c|}{ Sample $^{\mathrm{u}}$} & \multicolumn{2}{|c|}{ Cost for 100 samples $^{v}$} \\
\hline & DI SOw $^{w}$ & NDI SO $^{x}$ & DI GF ${ }^{y}$ & NDI GF ${ }^{Z}$ & Supplies & Supplies + labor \\
\hline ELISA & 90 & 100 & 85 & 90 & $\$ 70$ & $\$ 190$ \\
\hline RT-PCR & 100 & 100 & 100 & 100 & $\$ 980$ & $\$ 1,280$ \\
\hline DTBIA & 95 & 100 & 95 & 100 & $\$ 140$ & $\$ 245$ \\
\hline I-DTBIA & 95 & 100 & 95 & 100 & $\$ 200$ & $\$ 300$ \\
\hline
\end{tabular}

u Results are the percentage of 50 field trees in which CTV was detected using CTV-specific antibody MAb 17G11 by I-DTBIA, DTBIA, and ELISA, or by RT-PCR described by Huang et al. (7).

${ }^{v}$ Costs are calculated on the basis of labor cost at $\$ 15 / \mathrm{h}$ and supply costs for chemical reagents, enzymes, membranes, disposal plastic containers, and pipette tips. Equipment costs are not included.

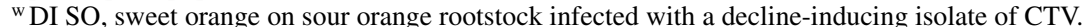

${ }^{x}$ NDI SO, sweet orange on sour orange rootstock infected with a non-decline-inducing isolate of CTV.

y DI GF, grapefruit on sour orange rootstock infected with a decline-inducing isolate of CTV.

${ }^{\mathrm{z}}$ NDI GF, grapefruit on sour orange rootstock infected with non-decline-inducing isolate of CTV.

Effect of storage time of the prereaction solutions on detection of CTV. Storage of the prereaction solutions of CTV antibodies and labeled secondary antibodies had some effect on the detection of CTV in the improved DTBIA test. The prereaction solutions of CTV antibodies and labeled secondary antibodies after storage for 5 to $60 \mathrm{~min}$ at $4^{\circ} \mathrm{C}$ or room temperature were stable and provided consistent strong sensitivity for the detection of CTV in the improved DTBIA test. However, the detection sensitivity of CTV decreased when prereaction solutions that had been stored for 24 to $48 \mathrm{~h}$ were used in the 20-min incubation procedure. When the incubation period was extended up to $40 \mathrm{~min}$, the prereaction solutions stored 24 to $48 \mathrm{~h}$ still provided enough sensitivity for detection of CTV in the improved DTBIA test (Table 3).

\section{DISCUSSION}

DTBIA is a reliable and sensitive procedure for detection of CTV. However, it usually requires 3 to $7 \mathrm{~h}$ to give results in tests using either a direct procedure or an indirect procedure, or even biotinstreptavidin (BIO/SA) procedures $(3,7)$. We improved the DTBIA by incubating the blots in a solution of CTV-specific antibodies mixed with labeled secondary antibodies. The improved DTBIA (I-DTBIA) procedure can detect CTV within $1 \mathrm{~h}$ with CTV-specific polyclonal and monoclonal antibodies and commercially available labeled secondary antibodies. Its sensitivity is similar to that of regular DTBIA, ELISA, and PCR (Table 4) (4,7). In addition, the prereaction solutions of CTV-specific antibodies and labeled secondary antibodies are stable at least $1 \mathrm{~h}$. Even after storage for 48 $\mathrm{h}$ at $4^{\circ} \mathrm{C}$ or room temperature, the prereaction solutions still work well for the improved DTBIA procedure when a longer incubation (up to $40 \mathrm{~min}$ ) is employed. The improved DTBIA procedure makes it possible to detect CTV for the purposes of research and diagnosis in $1 \mathrm{~h}$.

The major disadvantage of improved DTBIA (I-DTBIA) is that it is more costly in reagents than ELISA or regular DTBIA (Table 4). Although the concentrations, usually $1 \mu \mathrm{g} / \mathrm{ml}$ in PBS or PBS-B, of CTVspecific antibodies (IgG) were the same in the improved DTBIA, ELISA, and regular DTBIA tests, the concentrations of labeled secondary antibodies in the improved DTBIA test were higher than in ELISA and regular DTBIA tests. The dilutions were 1/5,000 for GAR-AP and 1/1,000 for GAM-AP in the improved DTBIA tests. This makes the improved DTBIA procedure cost more for detection of CTV than ELISA and regular DTBIA. The increased chemical cost is mostly offset by reduced cost of labor. Usually, the recommended dilution of GAR-AP for ELISA, DTBIA, and other immunoassays is $1 / 30,000$, and that of GAM-AP is $1 / 5,000$. When lower concentrations of labeled secondary antibodies were used, for example, GAM-AP $1 / 4,000$ or GAR $1 / 10,000$ in solutions that containing $1.0 \mu \mathrm{g} / \mathrm{ml} \mathrm{CTV}$ antibodies, the sensitivity of improved DTBIA for detection of CTV became weaker, and sometimes failed to give positive signals. To make sure the new procedure is sensitive enough and works well for detection of CTV, pretests should be conducted to determine the optimum concentrations of labeled secondary antibodies for the procedure. According to our results, the ideal concentrations are 1/1,000 for GAM-AP and $1 / 5,000$ for GAR-AP. The reasons why the improved DTBIA procedure requires higher concentrations of labeled secondary antibodies than ELISA and DTBIA procedures are not known. It may be related to the free immuno-globulin $\mathrm{G}$ $(\mathrm{IgG})$ in the working solutions. It is known that the lower the free IgG in a working solution, the higher the sensitivity of immunoassay for detection of antigens (8).

Both growers and scientists awaiting diagnostic results from the laboratory need the results quickly. They want to know whether their propagating source plant, field plant, survey test plant, or research plant is infected so decisions can be made relative to their business or to confirm or reject hypotheses. Reducing the "waiting time" by $80 \%$ has significantly improved our service and research efficiency.

We have shown that mixing the CTVspecific antibody with the AP-conjugated secondary antibody can reduce assay time to $1 \mathrm{~h}$ without loss of sensitivity or reliability. Hopefully, this DTBIA procedure could be useful for detection of other plant viruses and other pathogens such as bacteria and fungi.

\section{ACKNOWLEDGMENTS}

We thank S. M. Garnsey for providing PCA 1212 and MAb MCA13.

\section{LITERATURE CITED}

1. Bar-Joseph, M., Garnsey, S. M., Gonsalves, D., and Purcifull, D. E. 1980. Detection of Cit rus tristeza virus. I. Enzyme-linked immunosorbent assay (ELISA) and SDSimmunodiffusion methods. Pages 1-8 in: Proc Conf. IOCV, 8th. IOCV, Riverside, CA.

2. Cassab, G. I., and Varner, J. E. 1987. Immunocytolocalization of extension in developing soybean seed coats by immunogold-silver staining and by tissue printing on nitrocellulose paper. J. Cell Biol. 105:2581-2588.

3. Garnsey, S. M., Permar, T. A., Cambra, M., and Henderson, C. T. 1993. Direct tissue blot immunoassay (DTBIA) for detection of Citrus tristeza virus (CTV). Pages 39-50 in: Proc. Conf. IOCV, 12th. IOCV, Riverside, CA.

4. Huang, Z., Rundell, P. A., Guan, X., and Powell, C. A. 2004. Detection and isolate differentiation of Citrus tristeza virus in infected field trees based on reverse transcriptionpolymerase chain reaction. Plant Dis. 88:625629.

5. Lin, N. S., Hsu, Y. H., and Hsu, H. T. 1990. Immunological detection of plant viruses and a mycolasmalike organism by direct tissue blotting on nitrocellulose membranes. Phytopathology 80:824-828.

6. Lin, Y., Rundell, P. A., and Powell, C. A. 2002 In situ immunoassay (ISIA) of field grapefruit trees inoculated with mild isolates of Citrus tristeza virus indicates mixed infections with severe isolates. Plant Dis. 86:458-461.

7. Lin, Y., Rundell, P. A., Xie, L., and Powell, C. A. 2000. In situ immunoassay for detection of Citrus tristeza virus. Plant Dis. 84:937-940.

8. MacKenzie, D. 1990. Globulin conjugation methods. Pages 87-92 in: Serological Methods for Detection and Identification of Viral and Bacterial Plant Pathogens: A Laboratory Manual. R. Hampton, E. Ball, and S. De Boer, eds. American Phytopathological Society, St. Paul, MN. 
9. Nikolaeva, O. V., Karasev, A. V., Powell, C. A., Garnsey, S. M., and Lee, R. F. 1997. Modulation of the antigenic reactivity of the Citrus tristeza virus coat protein. J. Immunological Methods 206:97-105.

10. Permar, T. A., Garnsey, S. M., Gumpf, D. J., and Lee, R. F. 1990. A monoclonal antibody that disciminates strains of citrus tristeza virus. Phytopathology 80:224-228.

11. Rocha-Pena, M., and Lee, R. F. 1991. Serological technique for detection of Citrus tristeza virus. J. Virol. Methods 34:311-331.

12. Rocha-Pena, M. A., Lee, R. F., and Niblett, C. L. 1991. Development of a dot-immuno- binding assay for detection of Citrus tristeza virus. J. Virol. Methods 34:297-309.

13. Vela, C., Cambra, M., Sanz, A., and Moreno, P. 1988. Use of specific monoclonal antibodies for diagnosis of Citrus tristeza virus. Pages 5561 in: Proc. Conf. IOCV, 10th. IOCV, Riverside, $\mathrm{CA}$. 